\title{
Total Cellular Glycomics: A Glycomic Approach to Describe Cells and Streamline the Discovery Process for Cellular Biomarkers
}

\author{
総合グライコミクス：細胞を記述し、細胞マーカ一探索を加速する新しいアプローチ
}

\author{
Shinohara, Yasuro; Fujitani, Naoki; and Furukawa, Jun-ichi \\ Laboratory of Medical and Functional Glycomics, Graduate School of Advanced Life Science, and \\ Frontier Research Center for Post-Genome Science and Technology, Hokkaido University, Sapporo 001-0021, Japan \\ FAX: 81-11-706-9091, E-mail: yshinohara@sci.hokudai.ac.jp
}

(Received on February 8, 2013, accepted on February 22, 2013)

Key Words: omics-based biomarker discovery, stemness, interglycomic correlations, glycoblotting, $\beta$-elimination in the presence of pyrazolone

\begin{abstract}
Cell surfaces are coated with a variety of intricately arranged glycoconjugates such as glycoproteins, glycolipids and proteoglycans. Therefore, elucidating the expression profiles of glycans derived from various classes of glycoconjugates is important to understand cellular glycosylation homeostasis and systems biology glycomics. We have established a series of methodologies for the analysis of $\mathrm{N}$ - and $\mathrm{O}$-glycans derived from glycoproteins, glycosphingolipid glycans, glycosaminoglycans, and free oligosaccharides using mass spectrometry and liquid chromatography. Procedures to analyze each class of glycan were then combined to visualize the entire complement of sugars in the cellular glycome, so-called total cellular glycomics. When this technique was applied to various human cells including embryonic stem cells, induced pluripotent stem cells and various cells derived from normal and carcinoma cells, total cellular glycomes were found to be highly cell type-specific, demonstrating their utility as unique cellular descriptors. Total cellular glycomics can streamline the discovery of cellular biomarkers as demonstrated by the identification of known pluripotency biomarkers as well as novel candidate biomarkers.
\end{abstract}

\section{A. Introduction}

Glycoconjugates such as glycoproteins, glycolipids and proteoglycans play roles in various biological events on the cell surface. Many studies report structural analyses of cellular glycans in specific glycoconjugate classes such as $N$-glycans; however, total cellular analyses showing the relationship between different classes of glycans are scarce (1). Given that cell surfaces are coated with a variety of intricately arranged glycoconjugates and that certain carbohydrate epitopes (e.g., Lewis $X$, also known as stage-specific embryonic antigen (SSEA)-1) may be constituents of different glycoconjugates (e.g., $\mathrm{N}$-glycans, $\mathrm{O}$-glycans and glycosphingolipid (GSL) glycans) (2), a systematic overview of all the major
要 約

細胞表層は、糖タンパク質、糖脂質、プロテオグリカン といった種々の複合糖質で精密に覆われている。これらの複 合糖質に発現する糖鎖発現の全貌を解明することは、その細 胞における糖鎖発現の恒常性や糖鎖システム生物学を理解す るために重要である。筆者らは細胞に発現する糖タンパク 質由来の $N$-結合型糖鎖と $O$-結合型糖鎖、スフィンゴ糖脂質、 グリコサミノグリカン、遊離オリゴ糖を質量分析や液体クロ マトグラフィで解析する方法を開発してきた。個々の方法論 を統合し、細胞に含まれる複合糖質糖鎖の全体像（総合グラ イコーム）が俯瞰できるようになった。本法を用いて正常細 胞、ガン細胞、胚性幹細胞 (ES 細胞) 、人工多能性幹細胞 (iPS 細胞）間の比較を行うことにより、総合グライコームは高度 に細胞に特異的であり、細胞の記述子として有効であること が示された。本法は、細胞マーカー探索においてユニークな 方法となり、実際に既知の未分化細胞マーカーとともに新規 なマーカー候補を同定することに成功した。

\section{A. はじめに}

糖タンパク質、糖脂質、プロテオグリカンに代表される 複合糖質は、細胞表層でさまざまな生物学的に重要な働きを している。 $N$-結合型糖鎖 $(N$-glycans $)$ のように個別の複合糖 質については多くの構造解析例があるものもあるが、異なる クラスの複合糖質をまたぐ糖鎖の比較解析はそしい(1)。細 胞表層にさまざまなクラスの複合糖質群が巧妙に配置されて いること、糖タンパク質糖鎖 $(N$-glycan, $O$-glycan)、スフィ ンゴ糖脂質糖鎖 (GSL glycans) はしばしば共通のエピトー プを発現していること（例えばルイス $X$ (あるいはSSEA-1） 抗原) (2) 等から、主要な全ての細胞のグライコームを総合 
classes of oligosaccharides in the cellular glycome would help this glycome to be characterized. We recently proposed "total glycomics," which is an integrated analysis of various cellular glycans including $\mathrm{N}$-glycans, $\mathrm{O}$-glycans, GSL glycans, glycosaminoglycans (GAGs) and free oligosaccharides (FOSs) to quantitatively describe different classes of glycoconjugates in cells (3).

Cells are being increasingly used for disease diagnosis, disease therapy and drug discovery. Systems to characterize, select and control cells are essential for these applications. Many of the frequently used biomarkers, such as SSEA-3/4/5 and tumorrejection antigen Tra-1-60 and Tra-1-81, are glycoconjugates (4, $5)$. These glycomarkers were identified following the rather fortuitous development of specific anti-glycoconjugate antibodies. Most FDA-approved tumor markers are also either glycans or glycoproteins (e.g., AFP, CA10-9, CA125, CEA, PSA, and HER2/NEU) (6). Therefore, total cellular glycomics is expected to be a straightforward approach to identify novel and useful cellular markers. Here, we describe the methodologies of total cellular glycomics that we established, and the applications of these methodologies to classify and characterize human cells and to identify pluripotency biomarkers.

\section{B. Cellular Glycomic Analyses Based on Glycoblotting}

In 2008, we established a glyoblotting procedure to enable large-scale glycan analysis (7). A scheme of this glycoblotting procedure is shown in Fig. 1. In this procedure, glycans released from glycoconjugates can be chemoselectively captured on a high-density hydrazide-functionalized polymer via the hemiacetal groups at their reducing ends (8). After thorough washing to remove nonspecifically bound substances, unreacted hydrazide groups on the polymer surface are acetyl capped, and solid-phase methyl esterification of sialic acid residues is performed to render sialylated oligosaccharides chemically equivalent to neutral oligosaccharides. Finally, blotted and processed oligosaccharides are recovered in the form of oxime derivatives of the $O$-substituted aminooxy compound that were added by imine-exchange chemistry. This enables the simultaneous release and derivatization of glycans suitable for high performance liquid chromatography (LC) and mass spectrometry (MS) analyses. Glycoblotting consists of a series of processes; chemoselective ligation of reducing sugars onto a polymer, thorough washing, methyl esterification of sialic acid residues (optional), and labeling of reducing ends. Given that detection sensitivity is defined by the signal-to-noise ratio, glycoblotting is a feasible approach as the noise is reduced by chemoselective glycan ligation and thorough washing, and the signal is increased by an optimized labeling strategy based on imine exchange. Notably, all glycoblotting processes can be performed on multiwell filter plates, meaning
的にみることが重要と考えられる。我々は、最近、細胞に発 現する $N$-glycans, $O$-glycans, GSL glycans, グリコサミノグリカ ン (GAGs)、遊離オリゴ糖 (FOSs) の5つの異なるクラスの 糖鎖を統合的に解析する「総合グライコミクス」を提案した (3)。

診断、治療、および創薬のために細胞を利用する重要 性が高まり続けている。それに伴い、細胞の特性評価、選 別、品質の管理のためのシステムが必須となる。SSEA-3/4/5 や Tra-1-60, Tra-1-81 をはじめとする細胞マーカーの多くが複 合糖質であることが知られている $(4,5)$ 。これらの糖鎖マー カーは、特異的なモノクローナル抗体の開発の結果見いださ れたものである。また、FDAで認可されている腫瘍マーカー の多く（例えばAFP, CA10-9, CA125, CEA, PSA, and HER2/ NEU）も糖鎖または糖タンパク質である(6)。したがって、 細胞の総合グライコミクスは新規な細胞マーカーを探すう えで有効なアプローチとなることが期待できる。本稿では、 我々が確立した総合グライコミクスのための方法論と、本法 によるヒト由来細胞の分類、特性評価及び未分化マーカー探 索のアプローチを紹介する。

\section{B. グライコブロッティング法に基づく細胞のグライコー 么解析}

我々は2008年に、糖鎖の大規模解析を実現するグライ コブロッティング法を確立した（7）。グライコブロッティン グ法による糖鎖解析スキームを図 1 に示す。複合糖質から遊 離した糖鎖は、還元末端にへミアセタール基を有することか ら、高密度にヒドラジド基を表出する固相担体に化学選択的 に捕捉することができる $(8)$ 。夾雑物を徹底的に洗浄により 除き、未反応のヒドラジド基をアセチルキャップした後、中 性糖鎖と酸性糖鎖の質量分析による同時分析を可能とするた めに固相上でシアル酸のメチル化修飾を行う。最後に、捕捉 された糖鎖は $O$-置換アミノオキシ化合物存在下にイミン交 換によってその誘導体として、回収することができる。すな わち、糖鎖の固相担体からの切断と同時に、LCや質量分析 に有利な誘導体化を行うことができる。グライコブロッティ ング法は還元糖のみを選択的に捕捉し、精製後にシアル酸の メチルエステル化や還元末端の標識を行うまでの一連の過程 を指す。検出感度はシグナルーノイズ $(S / N)$ 比によって決定 されるので、ケモセレクティブな捕捉と徹底的な洗浄でノイ ズを低減し、イミン交換で適当な標識を導入してシグナルを 増大する本法は、S/N比を劇的に改善する合理的なアプロー チである。グライコブロッティング法における全ての工程は 


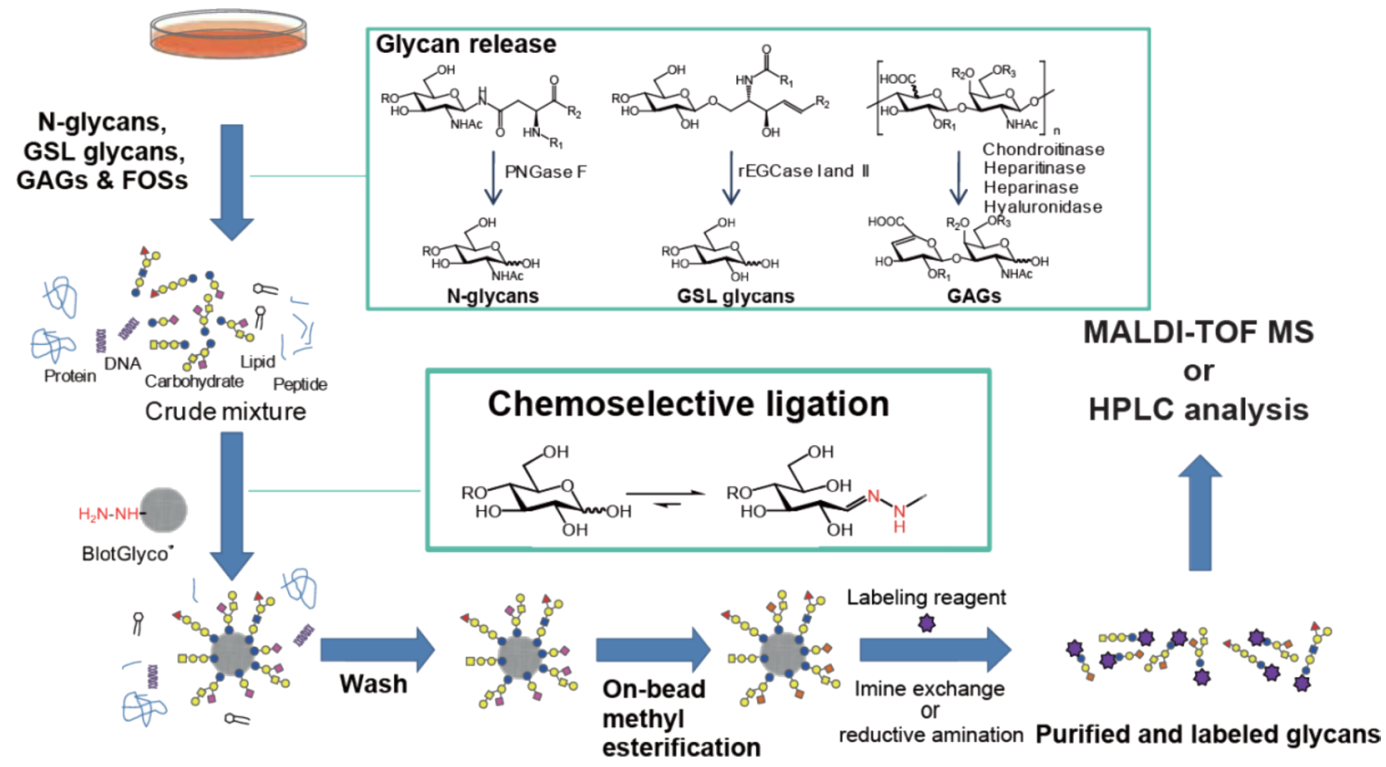

Fig. 1. Schematic diagram of the glycoblotting procedure for cellular glycomics of $\mathbf{N}$-glycans, GSL glycans, GAG disaccharides and FOSs. $N$-glycans, GSL glycans and GAG disaccharides obtained by specific enzymes as well as extracted FOSs are chemoselectively enriched and purified by glycoblotting, and are finally recovered in derivatized forms.

glycomic analysis is readily multiplexed (e.g., in a 96-well format). Here, we described how samples are prepared with a focus on particular types of cellular oligosaccharides, such as $N$-glycans, FOSs, GSL glycans, and GAGs.

\section{B-1. N-Glycans and FOSs}

Protein $N$-glycosylation plays important roles in the folding, oligomerization, sorting and transport of proteins (9). The removal of $N$-glycans from glycoproteins mediated by peptide $N$-glycosidase F (PNGase F) is useful as this can produce reducing sugars from glycopeptides regardless of the structures of their $N$-glycans (10).

FOSs are generated by $\boldsymbol{N}$-glycoprotein catabolism, which occurs via two distinct metabolic pathways: the endoplasmic reticulum-associated degradation of misfolded newly synthesized $N$-glycoproteins and the mature $N$-glycoprotein turnover pathway (11). Since the structures of FOSs are identical or very similar to those of $N$-glycans, it is essential to separate FOSs from glycoconjugates prior to analysis or to subtract background FOSs from the final analytical readout.

To maximize the recovery of cellular $N$-glycans and FOSs, cell pellets containing $10^{5}-10^{6}$ cells are homogenized in $100 \mathrm{mM}$ Tris-acetate buffer supplemented with $2 \%$ sodium dodecyl sulfate as a surfactant. Following reductive alkylation and ethanol precipitation, the supernatants (including FOSs) and precipitated proteins (including glycoproteins) are separated by centrifugation. The collected proteins are digested with trypsin, and then deglycosylated with PNGase F to generate free $N$-glycans. Both reductive alkyla-
マルチウェルフィルタープレートの上で完了できるため、グ ライコーム解析の並列処理 (例えば96ウェル) が容易である。 この章では、細胞に含まれる $N$-glycans, FOSs, GSL glycans お よびGAGsの試料調製法について述べる。

B-1.N-GlycansおよびFOSs

タンパク質の $N$-グリコシル化はタンパク質のフォール ディング、オリゴマー形成、選別や輸送などにおいて重要な 役割を担っている $(9)$ 。糖タンパク質からの $N$-glycans の遊離 には、PNGase Fが非常に有用であり、糖鎖の構造に依存せ ず、還元末端を有する糖鎖を遊離させることができる $(10)$ 。

FOSs は $N$-glycans が結合するタンパク質の異化の過程で 生成し、正しく折りたたみできなかったタンパク質の小胞体 関連分解 (ERAD) 及び成熟した糖タンパク質の代謝過程で 生成する (11)。FOSs の構造は $N$-glycans と同一か極めてょく 似ているので、 $N$-glycans の解析のためには、糖夕ンパク質 からあらかじめFOSsを除いておくか、FOSsの定量值を差し 引く必要がある。

細胞中に含まれる $N$-glycans の回収効率を最大化するた めに、 $1 \times 10^{5}$ から $1 \times 10^{6}$ 個程度の細胞ペレットを $2 \% \operatorname{SDS}$ を 含むトリス酢酸緩衝液中でホモジナイズすることで完全に可 溶化し、細胞破砕液とする。還元アルキル化の後にエタノー ル沈殿を行い、FOSs を含む上清と(糖)タンパク質を含む沈 殿に分離することができる。沈殿画分はトリプシン消化を施 


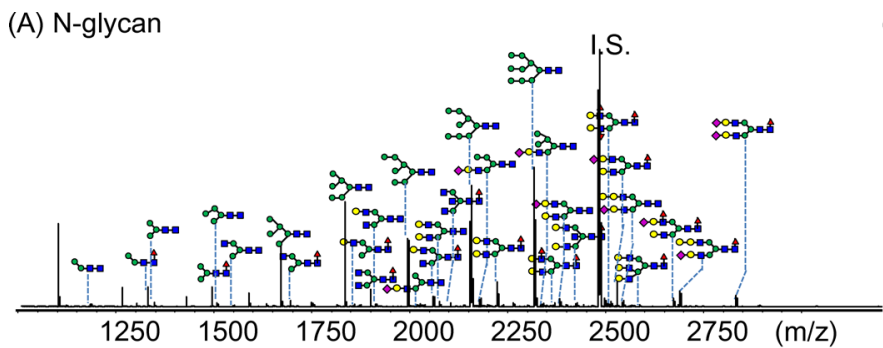

(D) O-glycan

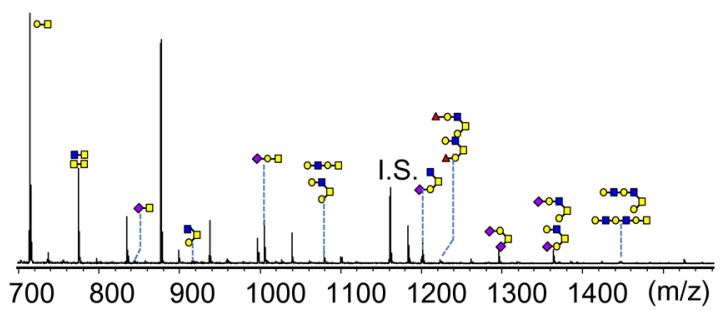

(B) FOS

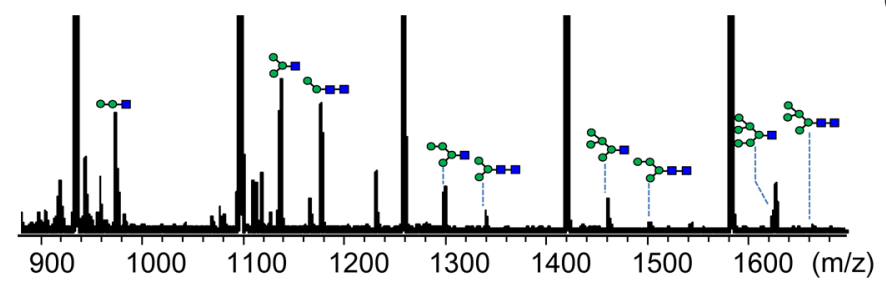

(E) GAG

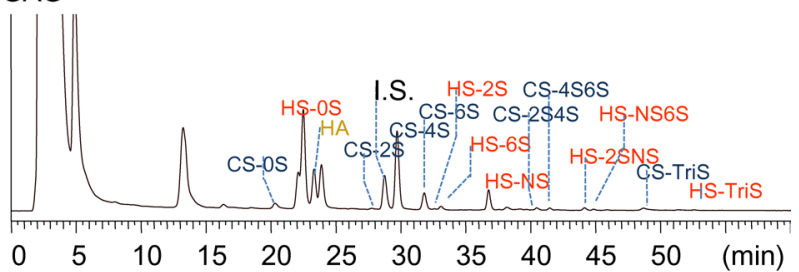

(C) GSL

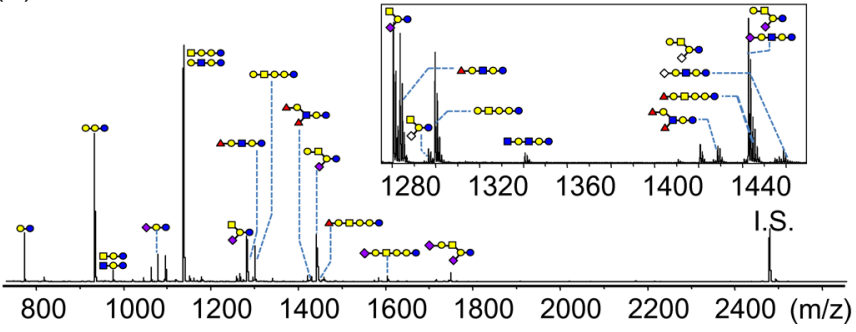

Fig. 2. Representative MS spectra and ZIC-HILIC chromatogram showing the glycomics profiles of iPS1A cells. MALDI-TOF MS spectra of (A) $N$-glycans, (B) FOSs, (C) GSL glycans and (D) $O$-glycans, and the ZIC-HILIC chromatogram of (E) GAG disaccharides. Putative structures are shown.

tion and trypsin digestion are important to maximize the efficiency of PNGase F digestion (12). Released $N$-glycans and fractionated FOSs are subjected to glycoblotting separately, where they are purified and labeled with aoWR (13), a highly sensitive tag for MALDI-TOF, and then subjected to MALDI-TOF MS analysis. MALDI-TOF MS spectra of the profiles of $N$-glycans and FOSs of iPS1A cells are shown in Figs. 2A and B.

\section{B-2. GSL Glycans}

GSLs are glycolipids that are attached via their glycan group to the head group of ceramides. GSLs form a functional microdomain called a "lipid raft" on cellular membranes together with cholesterols, membrane-spanning proteins and GPI-anchored proteins (14). GSLs are classified according to their glycan structure into ganglio, (iso)globo and (neo)lacto series. GSLs exhibit cell typespecific expression patterns and are often used as biomarkers. Five CD markers are GSLs, namely CD17 (LacCer), CD60a (GD3), CD60b (9-O-acetyl GD3), CD60c (7-O-acetyl GD3), and CD77 (Gb3) (15). Moreover, the globo series of GSLs are rich in undifferentiated cell markers such as SSEA-3 (Gb5), SSEA-4 (sialyl Gb5) and globo $\mathrm{H}$.
したうえで、PNGase Fによる脱グリコシル化を行う。還元 アルキル化及びトリプシン消化は PNGase Fによる消化効率 を最大化するうえで極めて効果的である (12)。遊離した $N$ glycans および分画したFOSs はグライコブロッティングによ り精製され、糖鎖の高感度試薬である aoWR(13)によって標 識され、MALDI-TOF解析に供される。iPS1Aの $N$-glycans お よびFOSsのMSスペクトルを図2A, Bに示した。

\section{B-2. GSL Glycans}

GSLs はセラミドの頭部に糖鎖修飾を受けた糖脂質であ り、コレステロールや膜貫通タンパク質、およびGPIアン カータンパク質などと共に細胞膜上で「脂質ラフト」と呼 ばれる機能に富んだ膜ミクロドメインを形成する (14)。糖 鎖構造により、GSLsはガングリオ系列、（イソ）グロボ系 列、（ネオ）ラクト系列に分類される。GSLsは細胞に特有の 発現パターンを示し、しばしばバイオマーカーとして用いら れる。細胞表面抗原のCD分類では、CD17 (LacCer), CD60a (GD3), CD60b (9-O-acetyl GD3), CD60c (7-O-acetyl GD3), CD77（Gb3）の5種類がGSLsである(15)。またグロボ系列 
GSLs have highly complicated structures due to structural diversities in their glycan and ceramide moieties. Therefore, methods with high resolution and high sensitivity are needed to analyze the structures of intact GSLs; in recent years, LC-MS has been reported to be one such method (16-18). Analysis focusing on glycan moieties of GSLs following their release from lipids eliminates structural heterogeneities associated with the ceramide moieties. There are two approaches to separate oligosaccharides from ceramide in GSLs; one is an enzymatic treatment and the other is a chemical digestion. Chemical digestion is achieved by ozonolysis or osmium-catalyzed periodate oxidation to cleave the olefinic double bond of sphingosine, followed by alkaline treatment to release glycans based on a $\beta$-elimination-like reaction (19). For enzymatic treatment, specific endoglycoceramidases/ceramide glycanases found in leech and microorganisms are used to remove glycan moieties from GSLs $(20,21)$.

We recently established a procedure for quantitative structural analysis of cellular GSL-associated glycans using rhodococcal endoglycoceramidases (EGCases) and the aforementioned glycoblotting procedure (22). Total lipids are extracted from cell pellets and resuspended in chloroform-methanol solution by sonication, and oligosaccharides are subsequently released from GSLs by EGCases. There are three subtypes of enzymes in the EGCase family (21). We employed the mixture of EGCases I and II to maximize the release of glycan moieties from the major classes of GSLs (i.e., ganglio-, (neo)lactoand globo-series GSLs). Traditionally, a complicated purification system was required to remove lipophilic impurities during sample preparation prior to analysis, and it was standard to use anion exchange to separate acidic GSLs containing sialic acids such as ganglio series from neutral GSLs. The glycoblotting procedure substantially improves the throughput and quantitative performance of this analysis since it can purify GSL glycans without the need for a complicated purification system and it allows sialic acids to be neutralized (methylated) on beads. Figure $2 \mathrm{C}$ shows the MALDI-TOF spectrum of GSL glycans derived from iPS1A cells.

\section{B-3. GAGs}

GAGs are polysaccharides formed by tandemly repeated disaccharides, and they play important roles in various biological processes such as cell adhesion and growth, maintenance of extracellular matrix integrity, and signal transduction (23). Hyaluronan (HA), chondroitin sulfate (CS), heparan sulfate (HS), dermatan sulfate (DS) and keratan sulfate contain disaccharide units of GlcA $\beta 1 \rightarrow 3$ GlcNAc, GlcA $\beta 1 \rightarrow 3$ GalNAc, GlcA $\beta 1 \rightarrow 4$ GlcNAc, $\operatorname{IdoA} \beta 1 \rightarrow$ 3 GalNAc and Gal $\beta 1 \rightarrow 4$ GlcNAc, respectively. Each of these disaccharide units, except for those of keratan sulfate, contain tandem repeats of uronic acid and an amino sugar. All GAGs except for hyaluronan are frequently sulfated. Since some of the disaccharide
は、SSEA-3 (Gb5) や-4(シアリル化 Gb5)、さらにはグロボH として知られる未分化細胞マーカーの宝庫でもある。

GSLs は、糖鎖構造およびセラミドの脂肪鎖長の違いに 起因する著しい構造多様性を示すことから、その構造解析 において、感度とともに高い分解能が要求される。近年、 LC-MS が両者を満たす方法として報告されている(16-18)。 一方、GSL glycans を脂質から切断して糖鎖部分の構造解析 をすることは、セラミド部分の構造多様性を排除することが できる。GSLsから糖鎖を切断するためには化学的な手法と 酵素を用いた手法の二つのアプローチがある。化学的な手法 はセラミド鎖をオゾン分解もしくは過ヨウ素酸酸化でセラミ ド鎖を分解後、アルカリ条件下で $\beta$ 脱離様の反応により糖鎖 を脂肪鎖から切り出す方法である (19)。酵素法は主にヒルや 微生物から発見されたエンドグリコセラミダーゼ（セラミド グリカナーゼ）が用いられる $(20,21)$ 。

最近、我々は、ロドコッカス属から見出されたエンドグ リコセラミダーゼ (EGCases) と先述のグライコブロッティ ング法を用いた細胞の GSL glycans の定量的な構造解析法を 確立した $(22)$ 。クロロホルムーメタノール溶液中での超音波 処理によって細胞ペレットから総脂質を抽出し、EGCaseに よってGSLsから糖鎖を切断した。EGCaseには基質特異性が 異なる三つのサブタイプが存在するが(21)、我々はEGCase I と IIを組み合わせて、ガングリオ系、（ネオ）ラクト系、グ ロボ系の糖鎖の遊離効率を最大化した。従来、GSLs の構造 解析はサンプル調製の段階で、不要な脂溶性分子を除くため に高度な精製が必要であり、また、イオン交換によってガ ングリオ系列をはじめとしたシアル酸を含む酸性GSLs と中 性GSLs を分離することが定石であった。しかし、先述のグ ライコブロッティング法は、高度な精製能力を有し、さらに 固層上でシアル酸の中性化（メチル化）を達成できるため、 処理速度と定量性を大幅に改善することができる。図 $2 \mathrm{Cに}$ iPS1A 細胞から得られた MALDI-TOFスペクトルを示す。

\section{B-3. GAGs}

GAGs は、細胞接着や細胞増殖、細胞外マトリックスの メンテナンスやシグナル伝達などさまざまな役割を担う、二 糖の繰り返し構造からなる高分子量の多糖である $(23)$ 。七

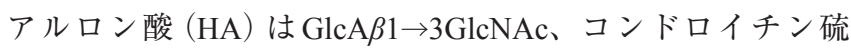

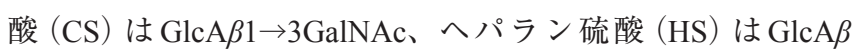
$1 \rightarrow 4 \mathrm{GlcNAc} 、$ デルマタン硫酸は $\operatorname{IdoA} \beta 1 \rightarrow 3 \mathrm{GalNAc}(\mathrm{DS}) 、 ケ$ ラタン硫酸 $(\mathrm{KS})$ は $\mathrm{Gal} \beta 1 \rightarrow 4 \mathrm{GlcNAc}$ 二糖の繰り返し構造 からなる。 $\mathrm{KS}$ 以外はウロン酸とアミノ糖の繰り返しを基本 とし、HA以外の GAGs はしばしば硫酸化される。基本構造 の類似性から、特異的な消化酵素によって得られる二糖ユ 
units obtained by specific enzyme digestion are structural isomers with the same molecular weight, an effective separation system such as LC is needed to analyze the structures of GAG disaccharides (24).

We have established a procedure for the quantitative analysis of GAG disaccharides using a combination of specific enzyme digestion, glycoblotting and zwitter-ionic hydrophilic chromatography (ZIC-HILIC) (25). Cell pellets are subjected to a wellestablished extraction protocol, which consists of defatting with chloroform-methanol solution and non-specific protease digestion with pronase. The collected chloroform-methanol layer is subjected to GSL analysis as described above. After ethanol precipitation, the recovered GAGs are digested with specific lyases to generate disaccharide units containing unsaturated bonds. Since HS, CS/DS, and HA disaccharides can be simultaneously analyzed in a single step using ZIC-HILIC chromatography, samples can be digested with a cocktail of enzymes containing heparinase, heparitinase, chondroitinase $\mathrm{ABC}$, and hyaluronidase SD. The resulting $\Delta$-disaccharides are purified from the complex mixture by glycoblotting and fluorescently-tagged with 2-aminobenzamide, and finally quantitatively analyzed by ZIC-HILIC chromatography. Since this method allows simultaneous disaccharide analysis of all three families of uronic acid-containing GAGs, it reduces the amount of sample required, simplifies the sample preparation protocol, and dispels concerns about contamination of GAG-degrading enzyme(s). Figure 2E shows a chromatogram of GAG disaccharides derived from iPS1A cells.

\section{Analysis of Cellular $\boldsymbol{O}$-Glycans Based on $\boldsymbol{\beta}$-Elimi- nation in the Presence of Pyrazolone Analogues}

As described above, $N$-glycans, GSL glycans, and GAGs disaccharides can be released using specific enzymes; thus, glycans with reducing ends can be purified and labeled by the glycoblotting procedure. However, $O$-glycans attached to serine/threonine residues of glycoproteins are mostly subjected to chemical digestions using reductive $\beta$-elimination because an analogous endoglycosidase for such glycoproteins is currently unavailable. Mild bases such as ammonia, alkylamine $\beta$-elimination, or classical hydrazinolysis are used (26). Reductive $\beta$-elimination, which was first reported in 1968 by Carlson (27), is still the most reliable technique to release $O$-glycans. Reductive $\beta$-elimination releases $O$-glycans in their reduced form (alditol) as a result of immediate in situ reduction by sodium borohydride. Reduction of the innermost sugar to alditol minimizes the side peeling reaction. Since in situ reduction causes transfer of the reducing ends of carbohydrates to the resultant unlabeled alditols, this method is incompatible with glycoblotting and other labeling techniques that target reduc-
ニットは分子量が同一の構造異性体である場合が多いため、 GAGs の二糖ユニット構造解析には、HPLCなどを用いた高 度な分離が必須である $(24)$ 。

我々は、GAGsの繰り返し二糖ユニットを、特異的な消 化酵素、グライコブロッティング法、さらに両イオン性親 水クロマトグラフィ（ZIC-HILIC）を用いて定量解析する方 法を確立した $(25)$ 。細胞ペレットをクロロホルムーメタノー ル溶液で脱脂し、プロナーゼで非特異的にタンパク質を分 解後、GAGs鎖を含むぺプチド断片をエタノール沈殿によ り回収した。ここで回収されるクロロホルムーメタノール溶 液はGSLs解析に供することができる。回収されたGAGs 鎖 は、GAG分解酵素（リアーゼ）群で消化し、不飽和結合を 有する二糖ユニットを得る。我々はZIC-HILIC HPLCにより、 HA、CS/DS、HS由来の主要な 2 糖ユニットの一斉分離法を 確立しているため、試料はへパリナーゼ、へパリチナーゼ、 コンドイチナーゼ $\mathrm{ABC}$ およ゙゙ヒアルロニダーゼ SDの混合物 で消化を行うことができる。得られた二糖ユニットはグライ コブロッティング法により精製し、蛍光タグ（2-アミノベン ズアミド）の導入を行い、ZIC-HILIC HPLCによる定量分析 を行う。1度の分析ですべてのウロン酸含有 GAGs の 2 糖組 成を解析できるため、試料必要量の低減、プロトコールの簡 略化、GAGs 分解酵素のコンタミの問題を低減することがで きる。図2EにiPS1A 細胞の GAGs の ZIC-HILICによるクロマ トグラムを示す。

\section{C. ピラゾロン共存下 $\beta$ 脱離反応に基づく細胞 $O$-Glycans の解析}

上述のように、 $N$-glycans, GSL glycans およびGAGs につ いては、特異的な酵素により還元末端を有する糖鎖を得られ るため、グライコブロッティング法により精製および標識が 可能となる。しかしながら、セリンおよびスレオニンに結合 している $O$-glycansは、それを広範に切り出す酵素は現在ま でに見いだされていないため、アンモニアやアルキルアミン 等による $\beta$ 脱離反応もしくはヒドラジン分解などの化学的な 手法で切断される (26)。1968年にCarlsonによって報告され た還元的 $\beta$ 脱離反応 $(27)$ は、いまでも $O$-glycans を遊離する うえで最も信頼できる方法である。本反応は、O-glycans を 切断するのと同時に水素化ホウ素ナトリウムによって系中で 素早く糖アルコールへと変換することで、副反応であるピー リング反応を最小限に抑えることができる。しかし、糖鎖の 還元末端がアルコールへと還元されるため、還元末端を利用 


\section{Cellular O-glycomic analysis based on BEP reaction}

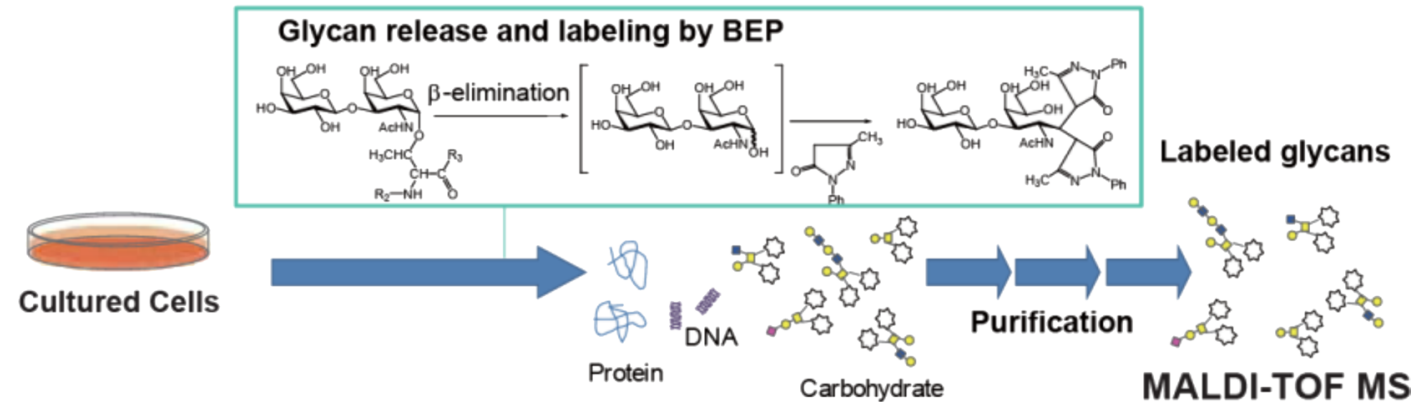

Fig. 3. Schematic diagram of cellular $O$-glycomics based on BEP. BEP allows simultaneous cleavage and labeling of $O$-glycans and concomitant labeling of the peptide moiety.

ing ends because alditols lack a hemiacetal group at their reducing ends.

Recently, Zauner et al., Wang et al., and we ourselves have introduced a novel one-pot $O$-glycome analytical method in which $O$-glycans are released from glycoproteins and labeled with pyrazolone analogues (28-30). This method, termed $\beta$-elimination in the presence of pyrazolone analogues (BEP), allows simultaneous labeling of released $O$-glycans with pyrazolone analogues and thus minimizes the undesirable peeling reaction. Furthermore, since deglycosylated peptides can be labeled with the same reagent, it can identify $O$-glycosylation sites. A scheme of cellular $O$-glycomic analysis using the BEP procedure is shown in Fig. 3. Ethanol precipitated proteins, which are prepared as described for $N$-glycans, are concentrated using an Amicon Ultra Centrifugal Filter (3K), and subjected to BEP. Combined with sequential solid-phase extraction, BEP allows analysis of cellular $O$-glycomics. A MALDITOF MS spectrum of the $O$-glycan profile of iPS1A cells is shown in Fig. 2D.

\section{Total Glycomics}

The protocols established to streamline individual glycomic analytical procedures for $N$-glycans, $O$-glycans, GAGs, GSL glycans and FOSs are summarized in Fig. 4. Total glycomics is anticipated to provide a straightforward approach to elucidate the network of intra- and inter-glycomic correlations (i.e., correlations within and between each individual glycome of various glycoconjugates).

As an example, total cellular glycomics analysis of the wildtype $\mathrm{CHO}$ cell line and its lectin-resistant mutant (Lec 8) is shown in Fig. 5 (3). Pie charts at the vertices of the pentagon correspond to the glycan expression profiles of $N$-glycans, FOSs, GAGs, GSL glycans and $O$-glycans. The size of the pie chart represents the absolute quantity of glycans per $100 \mu \mathrm{g}$ of cellular proteins, and the colors indicate the glycan structures. The Lec 8 mutation in-
したラベル化やグライコブロッティング法も適用できない。

最近、Zauner, Wang そして我々のグループが、ピラゾロ ン誘導体共存下の新規なワンポットの $O$-glycans 遊離・標識 法（ピラゾロン共存下ベータ脱離反応：BEP）を相次いで報 告した (28-30)。遊離した糖鎖が直ちにピラゾロン試薬によ りラベル化され、副反応であるピーリング反応を最小限に抑 えることができる。さらには脱離反応で脱グリコシル化され たペプチドも同一の試薬で標識できるため、糖鎖結合部位も 同定できる。本手法による細胞の $O$-glycans 解析法を図3に 示した。細胞中の糖タンパク質は、 $N$-glycansの項で述べた エタノール沈殿法により調製したタンパク質画分を限外滤過 （3K）を行った後にBEP反応を行う。段階的な固相抽出法と 組み合わせることで、細胞の $O$-グライコームの解析を行う ことができる。図2DにiPS1A 細胞から得られたMALDI-TOF スペクトルを示す。

\section{D. 総合グライコミクス}

$N$-glycans, $O$-glycans, GSL glycans, GAGs, FOSs の 個 々の 解析法を統合して確立された総合グライコミクスのプロト コールを図4に示す。総合グライコミクスは、種々の複合糖 質のそれぞれのグライコーム内、および個々のグライコーム 間のネットワークを明らかにするための直接的な方法となる ことが期待される。

一例として CHO細胞とそのレクチン変異株である Lec 8 の総合グライコームを図5に示す $(3)$ 。 5 角形の頂点の円グラ

フは、 $N$-glycans, $O$-glycans, GSL glycans, GAGs およびFOSs の 発現プロファイルを示し、円の大きさは $100 \mu \mathrm{g}$ タンパク質当 たりの糖鎖の発現量を、色は構造を表している。Lec 8 では UDP-Galのゴルジ体内腔への輸送が阻害されているため、す 


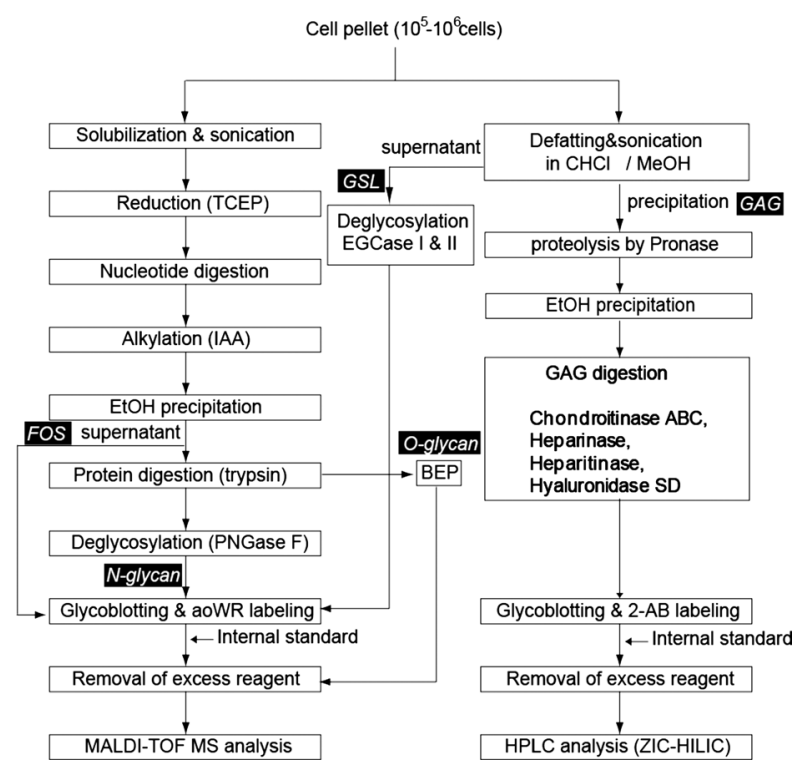

hibits translocation of UDP-Gal into the Golgi lumen and thereby dramatically reduces galactosylation of all glycoconjugates (31). The level of $O$-glycans and GSL glycans were substantially lower in Lec 8 CHO cells than in wild-type CHO cells. This is expected since galactosylation is essential for the synthesis of T-antigen and lactosylceramide, which are the precursors of most mucin-type $O$ glycans and GSL glycans, respectively. Interestingly, most of the $\mathrm{N}$-glycans in Lec $8 \mathrm{CHO}$ cells correspond to complex type glycans terminating in GlcNAc, while those in wild-type CHO cells correspond to high-mannose type glycans. This may reflect an attempt by Lec $8 \mathrm{CHO}$ cells to compensate for their reduced ability to synthesize GSL glycans and $O$-glycans. The level of GAG expression was 2.7-fold higher in Lec $8 \mathrm{CHO}$ cells than in wild-type $\mathrm{CHO}$ cells. Interestingly, galactose is required for the synthesis of proteoglycan GAGs because HS and CS/DS are synthesized on the so-called common GAG-protein linkage region $(\mathrm{GlcA} \beta 1 \rightarrow 3 \mathrm{Gal} \beta$ $1 \rightarrow 3 \mathrm{Gal} \beta 1 \rightarrow 4 \mathrm{Xy} \beta 1$-O-Ser) of core proteins. There are three UDPGal transporter candidates: LPG5A, LPG5B, and HUT1L. Lec 8 cells are deficient in LPG5A and LPG5B, but not HUT1L, indicating that LPG5A and LPG5B are not involved in the synthesis of the GAG-protein linkage region (32). Perturbation of a glycan synthetic pathway(s) can cause unexpected glycan expression profiles, which may be difficult to predict without the use of glycomics.

A summary of the quantitative structural analysis of glycans derived from 18 types of human cells including four embryonic stem (ES) cell lines and five induced pluripotent stem (iPS) cell lines, which are each derived from a different origin are shown in Fig. 6 (3). It is evident that the total cellular glycomes are highly cell type-specific, both quantitatively and qualitatively. The expression of a number of glycans was found to be characteristic of ES
Fig. 4. Streamlined protocol for the analysis of cellular $N$ - and $O$-glycans derived from glycoproteins, GSL glycans, GAGs, and FOSs.

ベての種類の複合糖質についてガラクトシル化が著しく低 減する (31)。O-Glycans と GSL glycans は、ともにその発現量 がCHOよりも顕著に低下した。ガラクトシル化はほとんど のムチン型 $O$-glycans と GSL glycans のプレカーサーとなる Tantigenおよびラクトシルセラミドの合成に必須であること から理にかなう観察といえる。興味深いことに、CHOの $N$ glycans の多くが高マンノース型糖鎖であるのに対して、Lec 8の N-glycans には非還元末端がGlcNAcで終結する複合型糖 鎖が多く認められた。これは、Lec 8 においてCHOに比較し て低下した $O$-glycans や GSL glycans の合成能の低下を補償し ようとしている可能性が考えられる。また、GAGs は Lec 8 において $\mathrm{CHO} の 2.7$ 倍の発現量が観察された。興味深いこと にガラクトースは GAGsの合成にも必要とされる。HS、CS/ DS はコアタンパク質にガラクトースを含む共通の4糖結合 領域 $(\mathrm{GlcA} \beta 1 \rightarrow 3 \mathrm{Gal} \beta 1 \rightarrow 3 \mathrm{Gal} \beta 1 \rightarrow 4 \mathrm{Xy} \beta 1-\mathrm{O}-\mathrm{Ser})$ を たて伸 長しているからである。UDP-Gal輸送体はLPG5A, LPG5B, and HUT1Lの三つがあり、Lec 8 は前2 者を欠損しているも

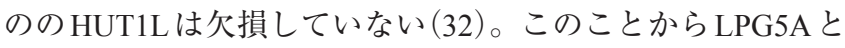
LPG5B はGAGs の結合領域の合成に関与していないことが示 唆される。本結果は、糖鎖合成系を攪乱したとき、総合グラ イコーム情報がないと検出できないような、予想外の糖鎖発 現変動が起こり得ることを示している。

本法により、 ES 細胞 4 株、由来の異なる iPS 細胞 5 株を 含む、計 18 種類のヒト由来細胞の糖鎖の総合グライコーム の解析を行った結果を図6に示す (3)。各細胞における糖鎖 

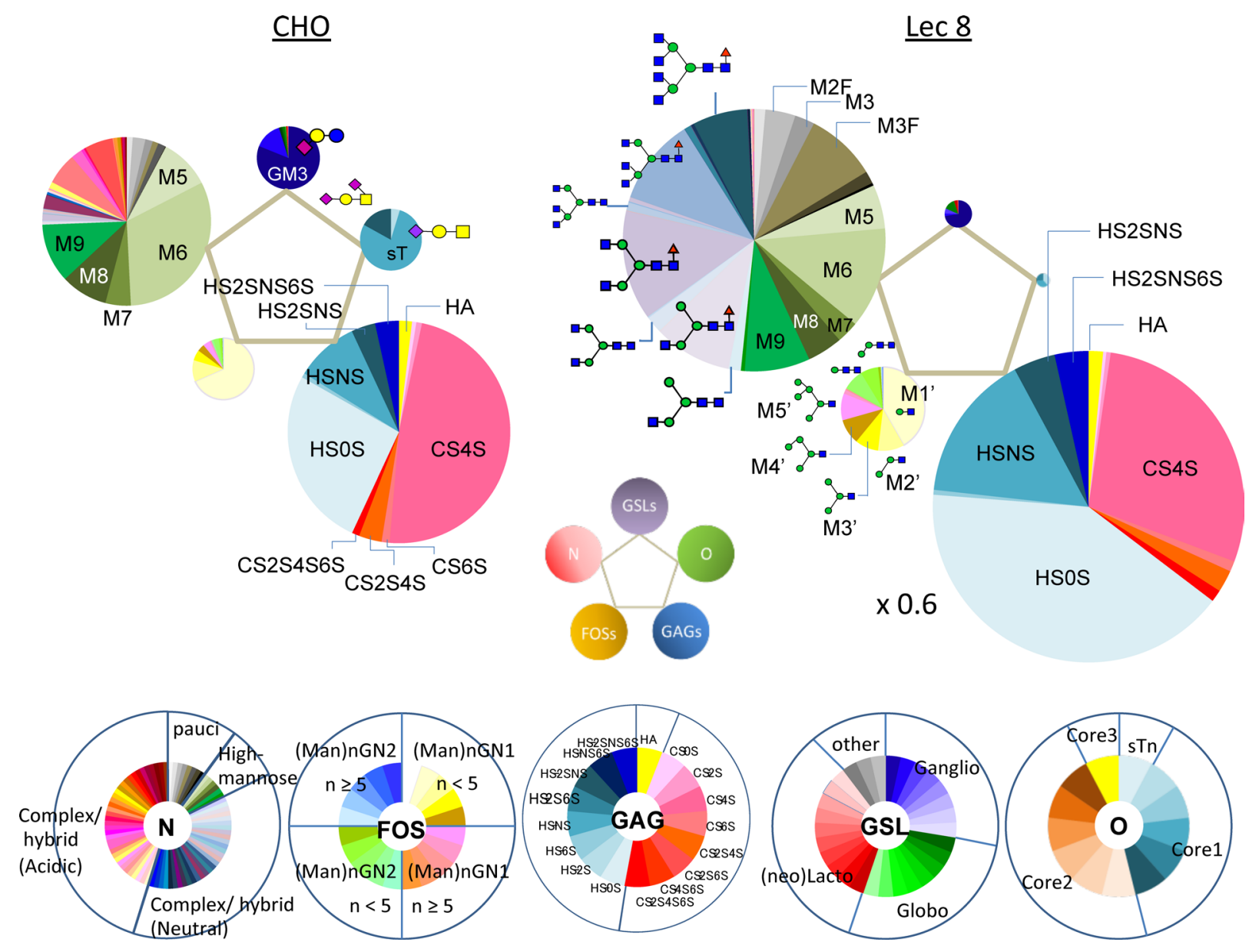

Fig. 5. Pentagonal cellular glycomic notations showing the entire glycome of the wild-type CHO cell line (left) and its lectin-resistant mutant, Lec 8 (right). The size and colors of the pie charts denote the absolute quantity of glycans (pmol/100 $\mu$ g protein) and the glycan structure, respectively. The size of the pie charts of GSLs and $O$-glycans of Lec 8 CHO cells are enlarged by 4 -fold (area ratio). The size of the pie chart of GAGs of Lec $8 \mathrm{CHO}$ cells is reduced by half (area ratio). Putative structures are shown.

and iPS cells as follows. GSL glycans and GAGs were the most abundant glycans. These cells expressed the GSLs SSEA-3 and -4, which are frequently used as markers of undifferentiated cells. Gb4 ( $\mathrm{Gal} \beta 1 \rightarrow 4 \mathrm{GalNAc} \beta 1 \rightarrow 4 \mathrm{Gal} \alpha 1 \rightarrow 3 \mathrm{Gal} \beta 1 \rightarrow 4 \mathrm{Glc}-\mathrm{Cer})$, which is the precursor of SSEA-3, accounted for approximately $40 \%$ of all GSL glycans and was the most abundant GSL glycan in these cells. Of the GAGs, HS and CS/DS were expressed at similar levels. Nonsulfated HS disaccharide (HS-0S) was abundant and accounted for approximately $80 \%$ of total HS. Monosulfated disaccharide at the 4-position of GalNAc (CS-4S) was the major component of CS/DS (approximately 70\% of total CS/DS). High mannose-type glycans were present in approximately $80 \%$ of total $N$-glycans and were abundant in high molecular weight glycans such as M9 and M8. The ratios of total cellular FOSs to total cellular $N$-glycans in hESCs and hiPSCs were significantly lower compared with those in carcinoma cells. Of the $O$-glycans, extended core 1 or core $2 O$ glycans that terminated with $\beta 1 \rightarrow 3$ galactose structures were char-
の発現量とその構造は、高度に細胞特異的であることが一 目で理解される。ES細胞やiPS 細胞における特徵として以下 のような観察ができる。GSL glycans と GAGsが他のクラス よりも相対的に多い。GSLsでは未分化細胞マーカーとして 広く利用されているSSEA-3,-4の発現が認められ、SSEA-3 の前駆体である Gb4 $(\mathrm{Gal} \beta 1 \rightarrow 4 \mathrm{GalNAc} \beta 1 \rightarrow 4 \mathrm{Gal} \alpha 1 \rightarrow 3 \mathrm{Gal} \beta 1 \rightarrow$ 4Glc-Cer) が最も多く発現していた（全 GSL glycans の約 40\%)。GAGはHS と CS/DS の割合がほぼ均等であり、HS は 硫酸化を受けていないHS-0S が多い（全HS の約 80\%）のに 対し、CS/DS はGalNAcの 4 位が硫酸化されたCS-4S が最も 多かった（全CS/DSの約 70\%）。N-glycansに関しては、高マ ンノース型の割合が高く（全 $N$-glycans の約 $80 \%$ )、特にM9 やM8など高分子量のものが多いのが特徵である。FOSs の発 現量は、 $N$-glycans の約 $1.4 \%$ 程度であり、他の細胞よりも有 


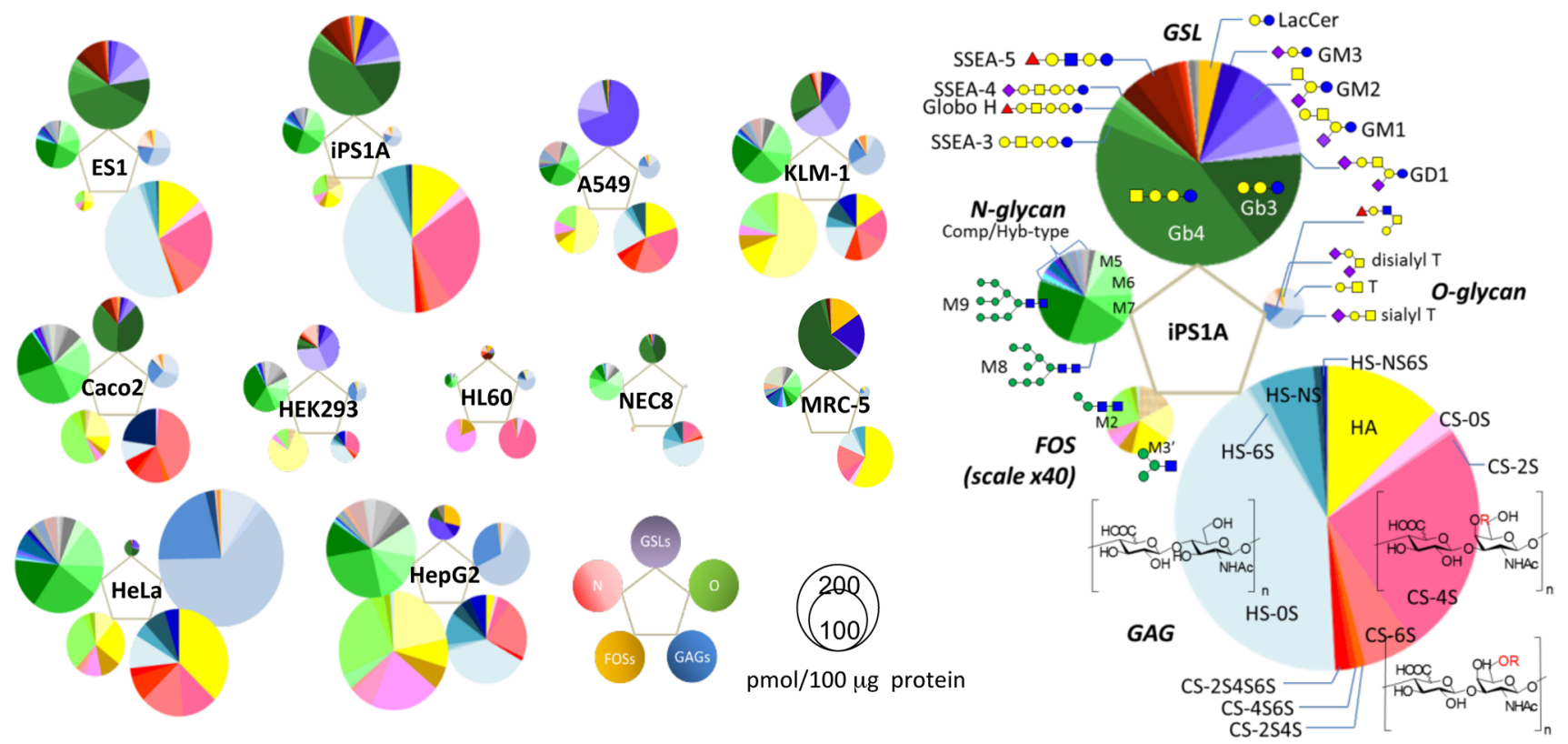

Fig. 6. Comprehensive glycomic profiles of various human cell types. Entire glycomic profile for ES cells (ES1), iPS cells (iPS1A), cancer cell lines including A549, KLM-1, Caco2, HEK293, HeLa, HepG2 and HL60, embryonic carcinoma cells (NEC8) and a normal cell line (MRC5) are shown as described in Fig. 5.

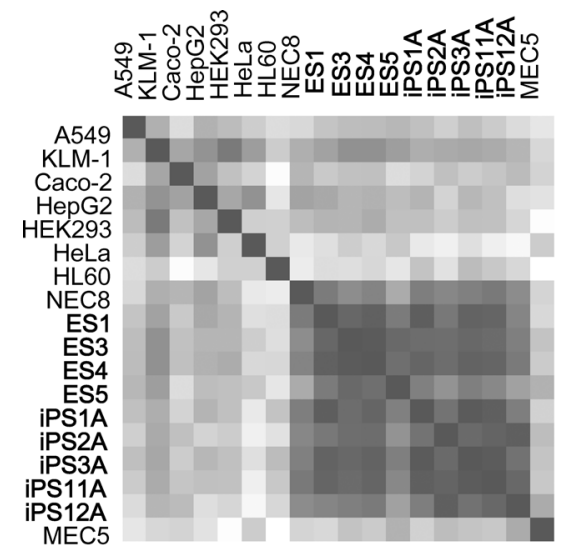

All glycome

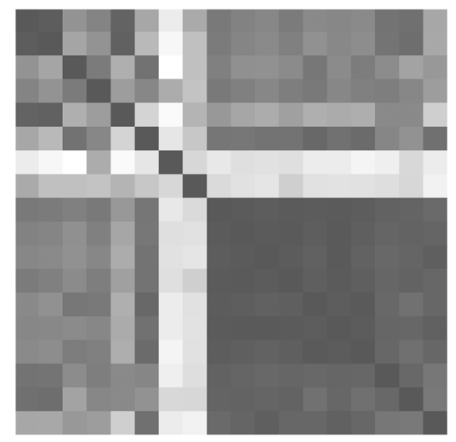

FOS

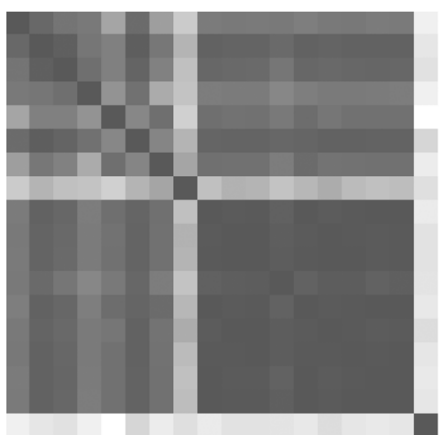

N-glycan

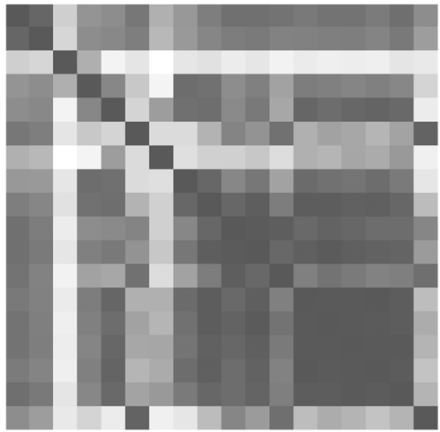

GAG

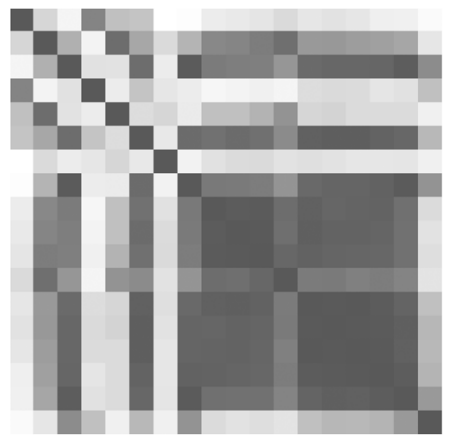

GSL

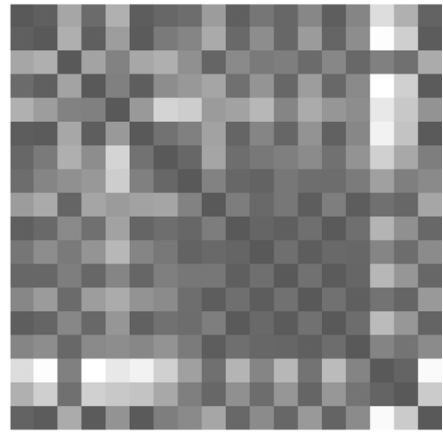

O-glycan

Fig. 7. Correlation matrix of each glycome. The correlation coefficient (r) value was used to distinguish different cell types from each other. 
(A)

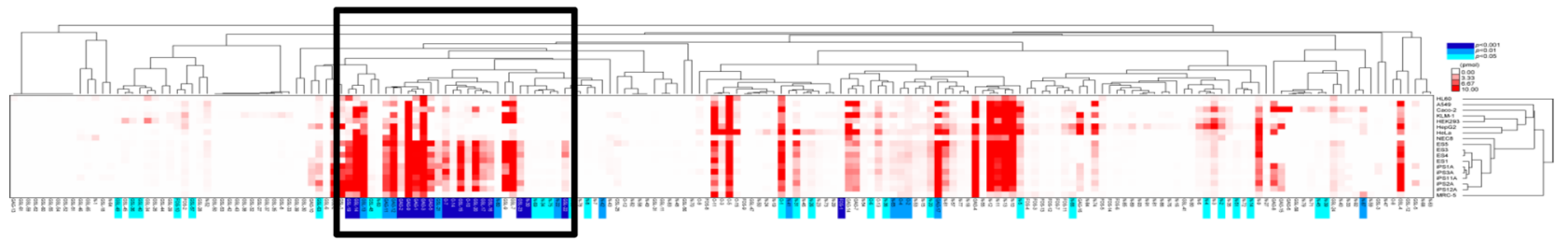

(B)

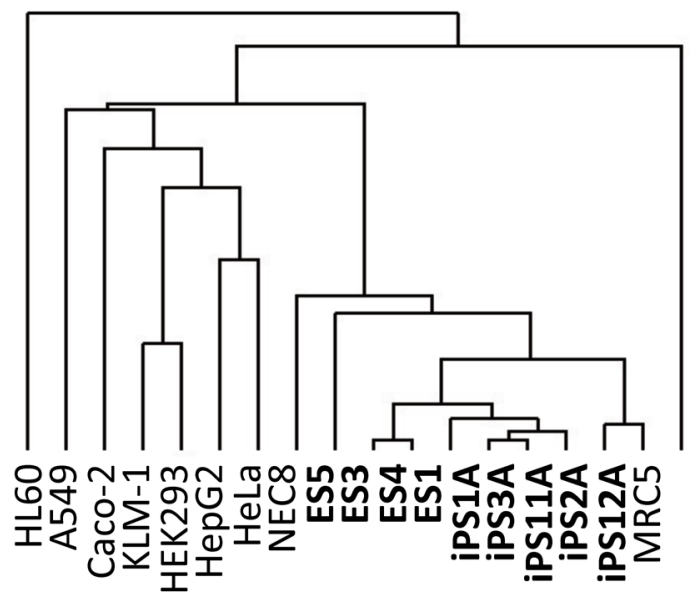

(C)

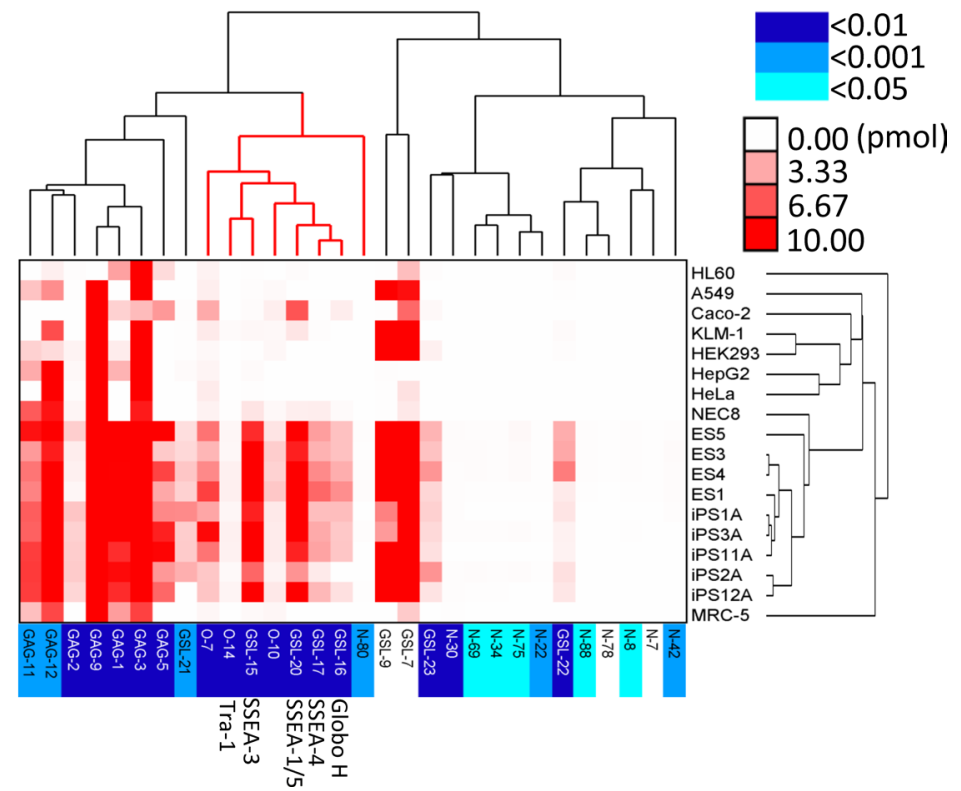

Fig. 8. Classification of cells and glycans by total cellular glycomics. (A) Unsupervised cluster analysis. The absolute amount of each glycan (pmol/100 $\mu$ g protein) was analyzed using Cluster 3.0 software. (B) An enlarged view of the cellular dendrogram shown in A. (C) An enlarged view of the glycan dendrogram shown in A. Glycans are marked in a blue box based on the p-values calculated when comparing the expression level in stem cells (human ES cells and human iPS cells) and non-stem cells.

acteristically abundant in human ES cells and human iPS cells.

Figure 7 shows correlation coefficient analysis between the absolute amount (pmol per $100 \mu \mathrm{g}$ of cellular protein) of each detected glycan (approximately 200 glycans) and the cell lines. Although each individual glycome could discriminate stem cells from other cell types to a certain extent, the discrimination power was most efficient when quantitative information regarding the entire glycome was taken into account. The results of hierarchical cluster analysis are shown in Fig. 8. Similar to the correlation coefficient analysis, the stem cell group including ES and iPS cells were closely clustered and could be distinguished from non-stem cells (Fig. 8B). Interestingly, the NEC8 cell line, which is derived from a teratoma and has the ability to differentiate, was clustered into a clade adjacent to stem cells. It should be emphasized that absolute quantitation rather than relative quantitation allowed direct comparison of the expression levels of glycans originating from different types of glycoconjugates. Glycans derived from vari-
意に低い傾向を認めた。O-Glycansは、非還元末端に Galが $\beta$ $1 \rightarrow 3$ 結合した伸長型 core 1 または core 2 型糖鎖の発現が他の細 胞よりも有意に多い点で特徵的であった。

検出された約 200 種類の糖鎖の絶対定量值（タンパク質 $100 \mu \mathrm{g}$ 当たりの pmol）を用いて細胞間の相関解析を行った 結果を図7に示す。個々のグライコームも幹細胞を他の細胞 とある程度区別することが可能であったが、五つのクラス の包括的な定量解析を行うことによって、個々の単独での 解析よりもより明瞭に幹細胞と非幹細胞を区別することが 示された。階層型クラスター解析の結果を図8に示す。相関 解析と同様に、ES 細胞とiPS 細胞からなる幹細胞群はお互 いに近縁となり非幹細胞群から区別される結果が得られた (図 8B)。興味深いことに、多分化能を有する胚性腫瘍（テ ラトーマ）細胞である NEC 8 は幹細胞群の近縁にクラスタリ ングされた。相対定量ではなく絶対定量を行うことによっ て、異なるクラスの複合糖質糖鎖を直接比較できるように 


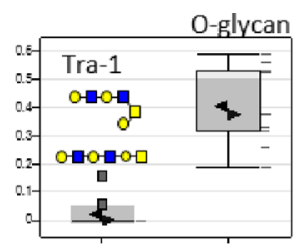

Non-stem Stem

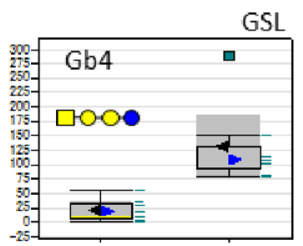

Non-stem Stem

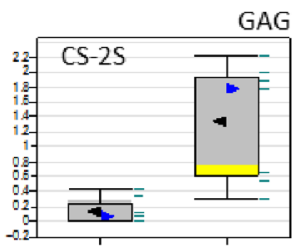

Non-stem Stem

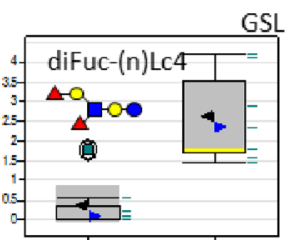

Non-stem Stem

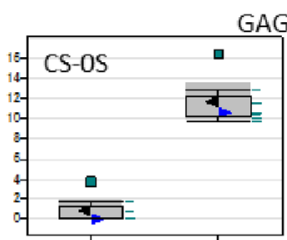

Non-stem Stem

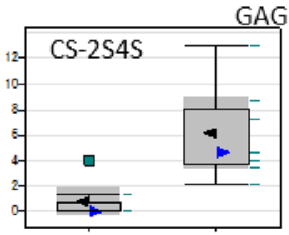

Non-stem Stem

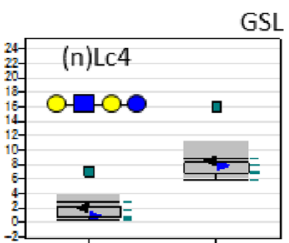

Non-stem Stem

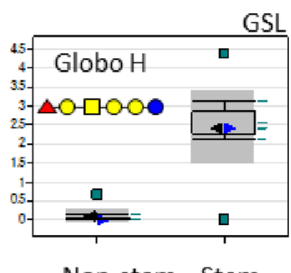

Non-stem Stem

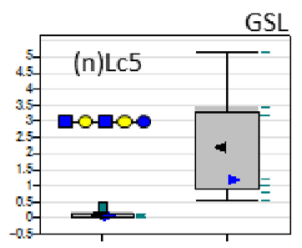

Non-stem Stem

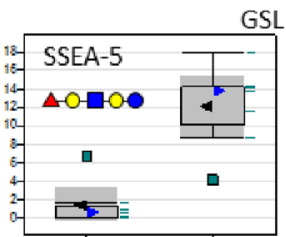

Non-stem Stem

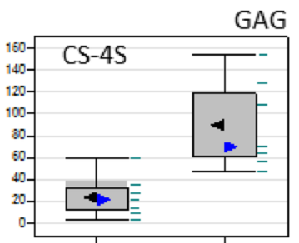

Non-stem Stem

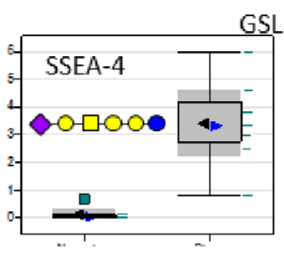

Non-stem Stem

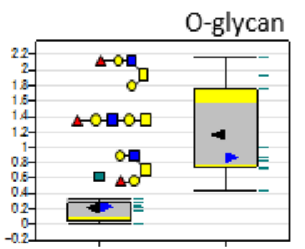

Non-stem Stem

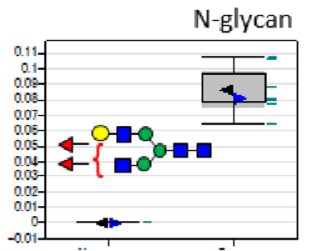

Non-stem Stem

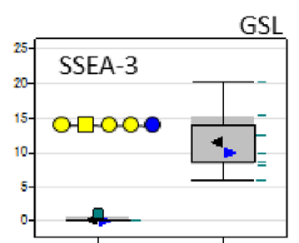

Non-stem Stem

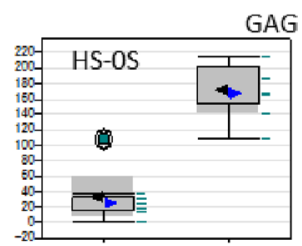

Non-stem Stem

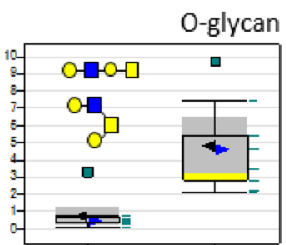

Non-stem Stem

Fig. 9. Box-and-whisker plots showing the total cellular levels of various glycans in stem cells (human ES cells and human iPS cells) and non-stem cells $(\boldsymbol{p}<\mathbf{0 . 0 0 1})$.

ous classes of glycoconjugates were successfully categorized into a single clade on the dendrogram, which helped elucidate interglycome correlations (Fig. 8C). Indeed, well-known pluripotency biomarkers such as SSEA-3, 4 and 5 (GSL glycans), as well as $\mathrm{Hex}_{3} \mathrm{HexNAc}_{3}$ (considered a Tra-1-60 and Tra-1-81 epitope (Oglycans)) (33), were clustered into a single clade. In other words, this analysis correctly identified these molecules as pluripotency biomarkers. This analysis further identified a panel of novel pluripotency biomarker candidates, demonstrating the power of this total glycomic approach for the discovery of cellular biomarkers. The 17 glycans whose expression levels significantly differed between stem cells and non-stem cells $(p<0.001)$ are candidates of novel markers of undifferentiated cells and are summarized in Fig. 9.

\section{E. Perspective}

Here, we described the concept of total cellular glycomics and our efforts to help develop this field. To our knowledge, this is the first attempt to determine all the major classes of glycans or the
なった。図 $8 C に$ 示す通り、異なるクラスの糖鎖が一つの分 岐群に分類され、異なるグライコーム間の相関を知る指標と なる。有名な未分化マーカーである GSLs 由来の SSEA-3, -4, -5, globo Hと O-glycans であり Tra-1のエピトープ構造と考え られる $\mathrm{Hex}_{3} \mathrm{HexNAc}_{3}(33)$ は一つの分岐群に分類された（図 $8 \mathrm{C})$ 。換言すれば、既知の複合糖質糖鎖未分化マーカーを予 備知識なしに同定することができたことになる。本解析はさ らに多数の新規な未分化候補マーカー候補を同定し、本アプ ローチが細胞マーカーを探索する上で極めて有用であること を実証した。幹細胞群と未分化細胞群間で発現量に有意差 $(p<0.001)$ が認められた 17 種類の未分化マーカー候補糖鎖 を図9にまとめた。

\section{E. 展望}

本稿では総合グライコミクスの概念とそれを実現するた めの我々の試みを記述した。我々の知る限り、細胞の主要な すべてのクラスの糖鎖を対象に、個々の糖鎖の相対的な濃度 
relative concentration of each type of glycan present within a cell line. Cells can be specifically described and characterized by comprehensive profiling of the structures and levels of the total glycans they express. The described method allows multiplexing analysis to improve the throughput of glycomic studies. It also allows absolute quantification, which is critical to compare the relative concentration of each type of glycan derived from various types of glycoconjugates. The number of cells required for the glycomic analyses outlined in this article is typically in the range of $10^{5}-10^{6}$ cells. Total cellular glycomics will have applications in a variety of fields, including comprehensive identification of pluripotency biomarkers and disease-related biomarkers. Overall, the ability to extensively analyze the cellular glycome in its entirety will open new avenues in systems biology glycomics. The methodologies need to be further improved to allow glycans to be detected more accurately.
を比較したのは初めての試みである。細胞はその発現する包 括的な糖鎖の構造や濃度によって特異的に記述や特徴づけが できた。ここで述べた方法論は並列処理が可能であり、グラ イコーム研究のスループットを改善する。また、さまざまな クラスの複合糖質由来の糖鎖の相対量を比較するうえで最も 重要な絶対定量を実現している。本稿で述べた方法論で必要 となる細胞の量は通常 $10^{5}-10^{6}$ 個程度である。総合グライコ ミクスは網羅的な未分化マーカーや疾患関連バイオマーカー の探索など広範な応用が期待できる。また、細胞全体のグラ イコームを包括的にみるアプローチは、システム糖鎖生物学 の実現に向けて大きな一歩になる。より多くの複合糖質糖鎖 をより高精度に検出するために、方法論はさらなる改良が求 められる。

\section{Acknowledgements}

The authors wish to thank many collaborators who have contributed to the original papers. The authors also wish to thank Dr. S. Mizumoto and Prof. K. Sugahara of Hokkaido University for fruitful discussion. This work was supported in part by the Special Coordination Funds for Promoting Science and Technology from the Ministry of Education, Culture, Sports, Science and Technology of Japan.

\section{References}

1. Furukawa, J., Fujitani, N., and Shinohara, Y. (2013) Biomolecules. 3, 198-225.

2. Varki, A., Cummings, R., Esko, J., Freeze, H., Hart, G., and Marth, J. (2009) Essentials of Glycobiology 2nd Edn. (Cold Spring Harbor Laboratory Press, Cold Spring Harbor, NY).

3. Fujitani, N., Furukawa, J., Araki, K., Fujioka, T., Takegawa, Y., Piao, J., Nishioka, T., Tamura, T., Nikaido, T., Ito, M., Nakamura, Y., and Shinohara, Y. (2013) Proc. Natl. Acad. Sci. U.S.A. 110, 2105-2110.

4. Kannagi, R., Cochran, N. A., Ishigami, F., Hakomori, S., Andrews, P. W., Knowles, B. B., and Solter, D. (1983) EMBO J. 2, $2355-2361$.

5. Lee, J. B., Kim, J. M., Kim, S. J., Park, J. H., Hong, S. H., Roh, S. I., Kim, M. K., and Yoon, H. S. (2005) Mol. Cells. 19, 31-38.

6. Ludwig, J. A., and Weinstein, J. N. (2005) Nat. Rev. Cancer. 5, 845-856.

7. Furukawa, J., Shinohara, Y., Kuramoto, H., Miura, Y., Shimaoka, H., Kurogochi, M., Nakano, M., and Nishimura, S. (2008) Anal. Chem. 80, 1094-1101.

8. Nishimura, S., Niikura, K., Kurogochi, M., Matsushita, T., Fumoto, M., Hinou, H., Kamitani, R., Nakagawa, H., Deguchi, K., Miura, N., Monde, K., and Kondo, H. (2004) Angew. Chem. Int. Ed. 44, 91-96.

9. Hebert, D. N., and Molinari, M. (2012) Trends Biochem. Sci. 37, 404-410.

10. Plummer, T. H. Jr., and Tarentino, A. L. (1991) Glycobiology 1, 257-263.

11. Suzuki, T., and Funakoshi, Y. (2006) Glycoconj. J. 23, 291-302.

12. Kita, Y., Miura, Y., Furukawa, J., Nakano, M., Shinohara, Y., Ohno, M., Takimoto, A., and Nishimura, S. (2007) Mol. Cell. Proteomics 6, 14371445.

13. Uematsu, R., Furukawa, J., Nakagawa, H., Shinohara, Y., Deguchi, K., Monde, K., and Nishimura, S. (2005) Mol. Cell. Proteomics 4, 1977-1989.

14. Hakomori, S. (2008) Biochim. Biophys. Acta. 1780, 1325-1346.

15. Wuhrer, M. (2013) Glycoconj. J. 30, 11-22.

16. Flangea, C., Serb, A., Sisu, E., and Zamfir, A. D. (2011) Biochim. Biophys. Acta. 1811, 897-917.

17. Müthing, J., and Distler, U. (2010) Mass Spectrom. Rev. 29, 425-479.

18. Serb, A., Schiopu, C., Flangea, C., Sisu, E., and Zamfir, A. D. (2009) J. Mass Spectrom. 44, $1434-1442$.

19. Hakomori, S. I. (1966) J. Lipid Res. 7, 789-792.

20. Li, Y. T., Ishikawa, Y., and Li, S. C. (1987) Biochem. Biophys. Res. Commun. 149, 167-172.

21. Ito, M., and Yamagata, T. (1986) J. Biol. Chem. 261, 14278-14282.

22. Fujitani, N., Takegawa, Y., Ishibashi, Y., Araki, K., Furukawa, J., Mitsutake, S., Igarashi, Y., Ito, M., and Shinohara, Y. (2011) J. Biol. Chem. 286, 41669-41679. 
23. Smith, R. A., Meade, K., Pickford, C. E., Holley, R. J., and Merry, C. L. (2011) Biochem. Soc. Trans. 39, 383-387.

24. Ly, M., Laremore, T. N., and Linhardt, R. (2010) J. OMICS. 14, 389-399.

25. Takegawa, Y., Araki, K., Fujitani, N., Furukawa, J., Sugiyama, H., Sakai, H., and Shinohara, Y. (2011) Anal. Chem. 83, $9443-9449$.

26. Wada, Y., Dell, A., Haslam, S. M., Tissot, B., Canis, K., Azadi, P., Bäckström, M., Costello, C. E., Hansson, G. C., Hiki, Y., Ishihara, M., Ito, H., Kakehi, K., Karlsson, N., Hayes, C. E., Kato, K., Kawasaki, N., Khoo, K. H., Kobayashi, K., Kolarich, D., Kondo, A., Lebrilla, C., Nakano, M., Narimatsu, H., Novak, J., Novotny, M. V., Ohno, E., Packer, N. H., Palaima, E., Renfrow, M. B., Tajiri, M., Thomsson, K. A., Yagi, H., Yu, S. Y., and Taniguchi, N. (2010) Mol. Cell. Proteomics 9, 719-727.

27. Carlson, D. M. (1968) J. Biol. Chem. 243, 616-626.

28. Zauner, G., Koeleman, C. A., Deelder, A. M., and Wuhrer, M. (2012) Biochim. Biophys. Acta. 1820, 1420-1428.

29. Wang, C., Fan, W., Zhang, P., Wang, Z., and Huang, L. (2011) Proteomics 11, 4229-4242.

30. Furukawa, J., Fujitani, N., Araki, K., Takegawa, Y., Kodama, K., and Shinohara, Y. (2011) Anal. Chem. 83, 9060-9067.

31. Stanley, P., Sundaram, S., and Sallustio, S. (1991) Glycobiology 1, 307-314.

32. Capul, A. A., Barron, T., Dobson, D. E., Turco, S. J., and Beverley, S. M. (2007) J. Biol. Chem. 282, 14006-14017.

33. Natunen, S., Satomaa, T., Pitkänen, V., Salo, H., Mikkola, M., Natunen, J., Otonkoski, T., and Valmu, L. (2011) Glycobiology 21, $1125-1130$.

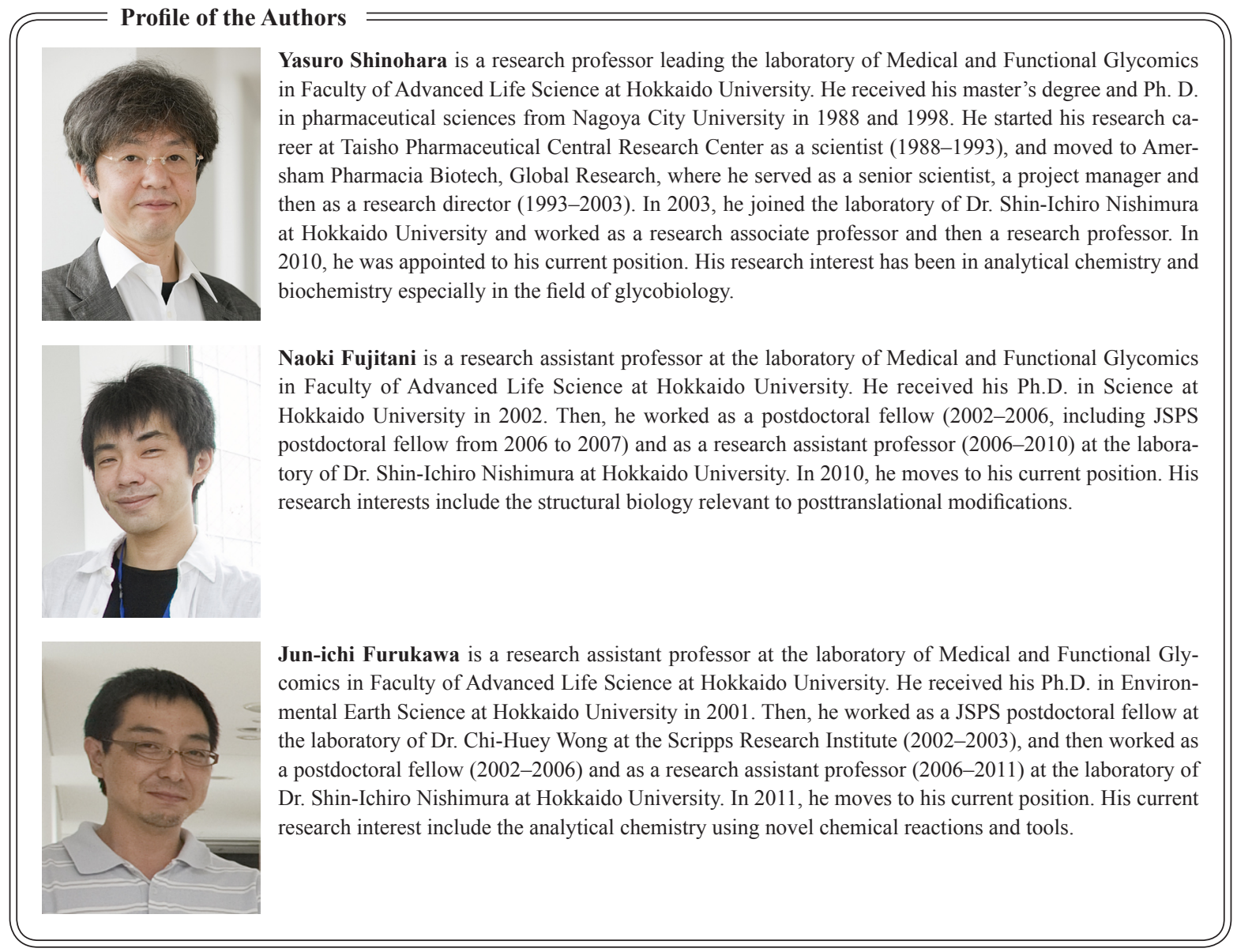

